\title{
PLAGIOGRANITIC ROCKS OF EVROS OPHIOLITE, NE GREECE
}

\author{
Magganas A. ${ }^{1}$ \\ ${ }^{1}$ National and Kapodistrian University of Athens, Faculty of Geology and Geoenvironment, \\ Department of Mineralogy and Petrology, Panepistimiopolis, 15784, Athens, \\ amagganas@geol.uoa.gr
}

\begin{abstract}
Dykes or small stocks of plagiogranitic rocks occur below the extrusive sequence and in mutually interpenetrating association with the sheeted dyke complex of the Evros Ophiolite, NE Greece. They are classified as tonalites, low silica trondhjemites (LST) and high silica trondhjemites (HST). Petrographic and geochemical data suggest they resemble oceanic plagiogranites of SSZ origin. Their normalized rock/ORG diagrams reveal ORG compatible element values, slightly depleted relative to ORG incompatible elements and $\mathrm{Ba}, \mathrm{Ta}$ and $\mathrm{Nb}$ negative anomalies. Plagiogranites also show subparallel, relatively flat REE patterns with variable Eu anomaly. As such geochemical features are also found in the dacitic to rhyodacitic lavas of Evros Ophiolite, it is assumed that plagiogranitic melts, especially of LST composition, presumably fed them. As a first approximation to plagiogranites origin, it is suggested tonalite and HST could have been generated by $5-15 \%$ partial melting of oceanic gabbros, whereas LST may possibly derive by fractional crystallization of a MORB type source. In a later stage, intense hydrothermal metamorphism affected the plagiogranites causing formation of peculiar epidositic spherical clots and veinlets.
\end{abstract}

Key words: Plagiogranite, trondhjemite, petrogenesis, partial melting, epidosite.

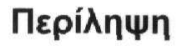

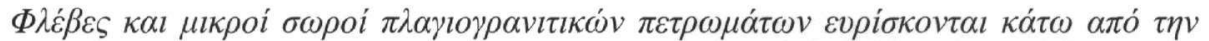

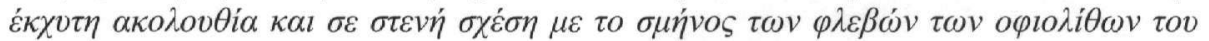

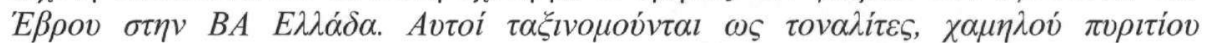

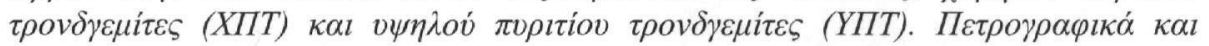

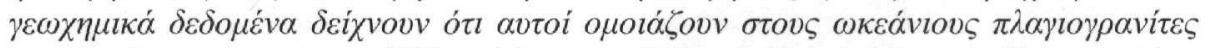

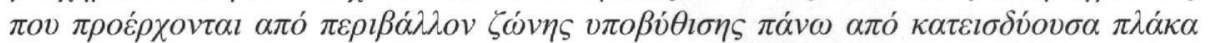

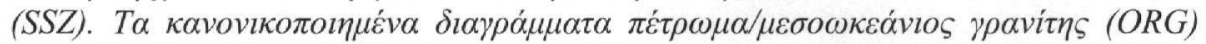

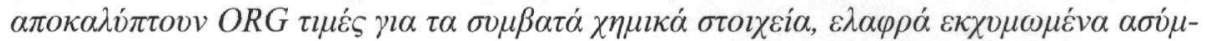

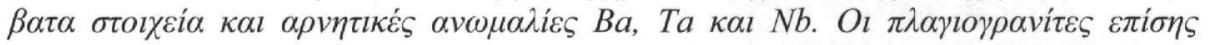

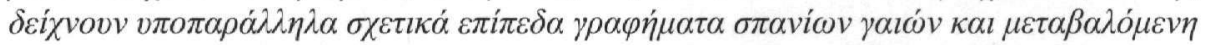

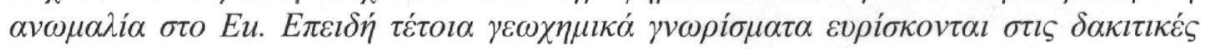

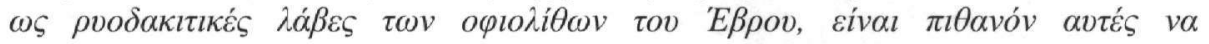

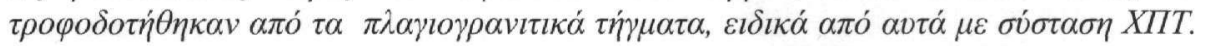

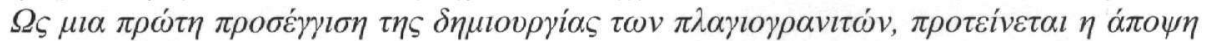

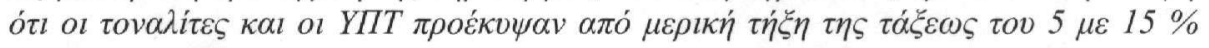

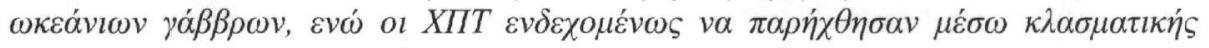




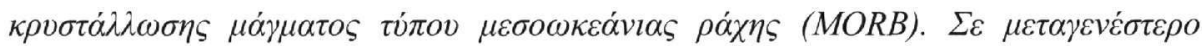

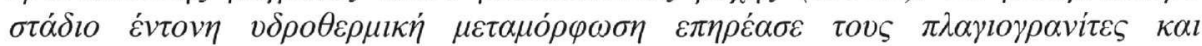

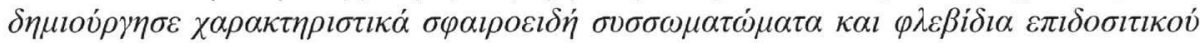
$\tau \dot{\pi} \pi 0 v$.

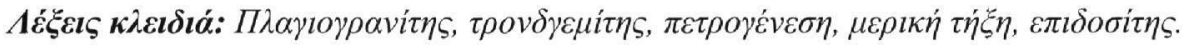

\section{Introduction}

Since long time ago but also in recent years much attention has been given to the study of exposed ophiolitic sequences as they represent on land oceanic crust and mantle. Among the various ophiolitic rocks, the most abundant are considered the ultramafic tectonites occurring at the bottom of the ophiolite pseudostratigraphic column and the extrusive rocks mainly in the form of pillow lavas on top of the whole sequence. Fewer studies have been focused on middle section magma chamber rocks and sheeted dyke complexes. Probably because they are less voluminous, especially plagiogranites, scarce in many ophiolites and geochemically not as useful as other ophiolitic portions are in discriminating geotectonic environment of ophiolite formation and evaluating magma source processes. However, plagiogranitic rocks are studied in many cases to show extreme differentiation procedures, which involve highly acidic magmas to have been generated from mafic precursors and to date with great accuracy the formation of the whole ophiolite (e.g. Coleman and Donato 1979, Bébien 1991, Floyd et al. 1998, Hatzipanagiotou and Tsikouras 1999, Dick et al. 2002, Koepke et al. 2007).

Evros ophiolite, with parts in NE Greece and SE Bulgaria, has been described as a dispersed and incomplete ophiolite, because its mantle section rocks are almost absent and plutonic section of the ophiolite is rather rarely exposed (Magganas 1988, Magganas et al. 1991, Magganas 2002, Bonev and Stampfli 2003). In this paper, we will describe upper magma chamber plagiogranitic rocks of this ophiolite occurring close to Didymotycho town, in close spatial association with gabbroic rocks and sheeted dyke complex. We will present new mineralogical, petrographical and major and trace element geochemical data in order to constrain on their geotectonic environment and petrogenesis. Our result contribute to the better understanding of the petrologic and geodynamic evolution of the innermost isopic zone of the Hellenides and may thus facilitate to resolve the problematical geologic history of the broader area of NE Greece and SE Bulgaria.

\section{Geological Outlines and Field Relations}

The Evros ophiolitic complex, outcropping in the area of Thrace both in NE Greek and SE Bulgarian territories, belongs to the Circum-Rhodope Belt. Parts of the complex are found in both Units of the CRB, the Drymos-Melia Unit and the Makri Unit (Papadopoulos 1982). It comprises rocks mostly of an ophiolitic magmatic series, whereas ultramafic mantle series rocks are quite seldom (Bigazzi et al. 1989, Magganas et al. 1991, Magganas 2002, Bonev and Stampfli 2003). The age of the ophiolite complex is considered to be Jurassic-Lower Cretaceous (Magganas et al. 1991, Magganas 2002). It overlays a Late Permian to Jurassic Metasedimentary Basement Series, which consists of marble, dolomite, limestone, calc-schist, phyllite and metaconglomerate and conformably underlies Cretaceous flyschoid sedimentary rocks and shelf facies limestone (Papadopoulos 1982, von Braun 1993). All these CRB rocks are suggested to be allochthonous, having been overthrusted as small nappe blocks or slices onto the Rhodope Massif (von Braun 1993, Barr et al. 1999). Both CRB rocks and the nearby Rhodope Massif are either intruded or unconformably overlain by Tertiary igneous and sedimentary rocks.

The various parts of the Evros ophiolitic complex are scattered in several localities; an occurrence that is mainly due to large scale faults actions or nappe movements, to the overlying Cainozoic rocks and to erosion. Regional and oceanic-hydrothermal metamoprhism affected almost all ophiolitic rocks, though in many circumstances primary mineralogical, petrological and geochemical features are well preserved. The uppermost stratigraphic layers of the complex are represented by prehnite-pumpellyite facies metavolcanics underlain by greenschists and 
greenstones of volcanic origin. Both upper and lower metavolcanics are mostly developed in the areas of Maronia, Makri, Melia, Didymotycho, Micro Derio and Metaxades-Madritsa (Fig. 1). Plutonic rocks, mostly gabbros, are usually associated with the greenschists and have been referred to occur in Krovyli-Petrota, Makri, Agriani, Didymotycho areas (Bigazzi et al. 1989, Frass et al. 1990, Magganas et al. 1991, Magganas 2002, Bonev and Stampfli 2005).

In the Petrota graben, a cumulitic sequence consisting of layered and pegmatoid gabbros, peridotites, pyroxenites, gabbronorites and anorthosites, is surrounded by isotropic granular gabbros crosscut by leucocratic plagiogranitic dykes (Bigazzi et al. 1989, Frass et al. 1990). A second limited occurrence of gabbroic and plagiogranitic rocks is located few kilometres west of Alexandroupolis near Makri. This small intrusion consists of a slightly-metamorphosed, lightgreen coloured, actinolitic metagabbros to tonalite with darker, more enriched in mafic minerals gabbroic enclaves and microgabbroic to quartz-dioritic dykes, $5-10 \mathrm{~cm}$ in thickness. In a seaside outcrop in the same area, a metavolcanic dyke about $1 \mathrm{~m}$ in thickness intrudes metagabbros. Within the metagabbros there are also thin quartz and/or epidositic veins of hydrothermal origin. Other exposures of plagiogranitic rocks are found in Argiani and in Psathades, $2 \mathrm{~km}$ south of Didymotycho. The latter is the best for study as it is located in a recently developed large quarry, which has been used for providing aggregates for the construction of the Egnatia Road branch leading to Orestias and Bulgaria. The intrusive rocks of the area comprise both plutonic and hypabyssal rocks of the ophiolite complex. They form an isotropic plagiogranite stock, with

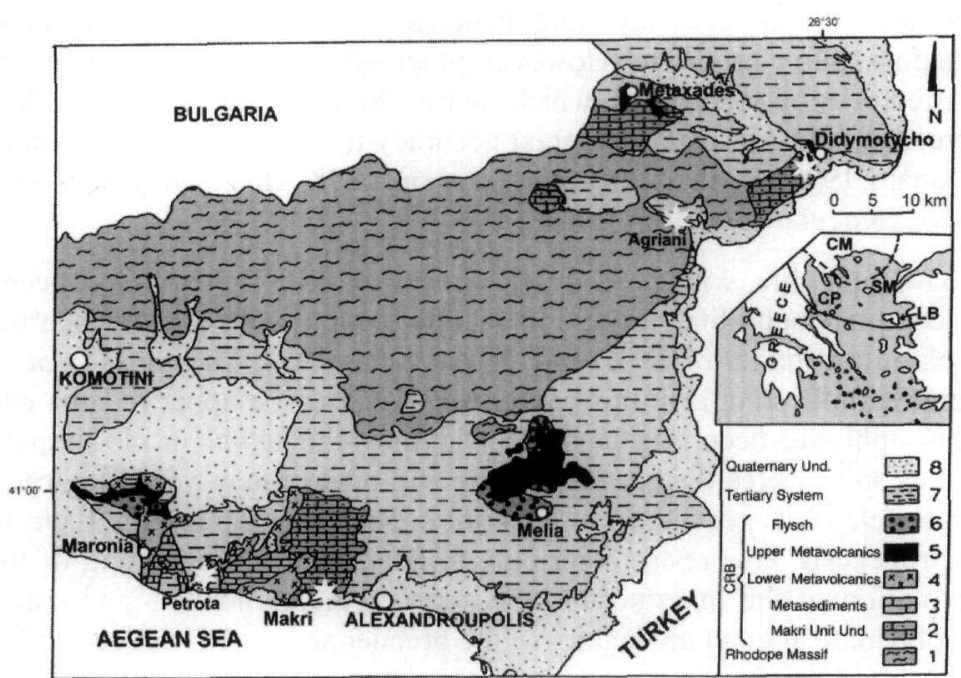
Figure 1 - Geological scetch map of Thracian Circum Rhodope Belt. In the inset the whole CRB is depicted. Central Macedonia (CM), Chalkidiki (CP) and Samothraki (SM). Plagiogranite occurrences are shown by white stars

a diameter of at least $200 \mathrm{~m}$, crosscut by abundant gabbros, quartz diorites and microgabbros sheets and dykes with a subparallel orientation. The mineral species are more or less the same throughout the granitoid stock, but their quantities from place to place show greater variability, leading according to IUGS nomenclature to several petrological types, from quartz diorite, tonalite or trondhjemite to granodiorite and leucogranites.

The above field relationships among various rock types suggest that both cumulate and non cumulate magma chamber series of an ophiolitic complex are developed in Evros ophiolite. The lower cumulate sequence is exposed in Petrota graben only, whereas the upper non cumulate sequence and sheeted dyke complex is found mostly northwards, extending over a larger area in the form of isolated bodies. However, this dispersed development is possibly an artifact due to postmagmatic reasons of tectonic origin during thrusting or continental obduction. Moreover, contact relationships between the various igneous rocks indicate that the intrusion sequence has changed at least once from mafic to felsic and vice versa or that both acid and basic melts probably coexisted. For instance in the area of Didymotycho, there are few fine-grained microgabbroic partly resorbed enclaves with boundaries blurred or well defined by mafic minerals accumulation, 
within fine to medium-grained plagiogranite, as well as mutually interpenetrating felsic and mafic dykes. In particular, microgabbroic and coarse-grained gabbroic dykes are intruding felsic plagiogranitic rocks more frequently with contacts showing either sharp or transitional chilled margins. Late very-fine grained to aphanitic basalt-andesitic dykes crosscutting also felsic rocks seem to be the youngest expression of the igneous activity in this plutonic sequence. These dykes are most probably the feeders of the lava flows and pillow-lavas of the mafic volcanic complex (upper metavolcanics) of Evros ophiolite occurring in a short distance northwards.

Metavolcanics of the upper extrusives of Evros ophiolite are classified as slightly metamorphosed low-Ca boninites, tholeiitic basalts and andesites, dacites-rhyodacites. They form massive and pillow lavas, dykes or they have been deposited as pyroclastic layers. Their primary mineralogy includes olivine (pseudomorphosed), $\mathrm{Mg}$ - to $\mathrm{Mg}$-Cr-augite, plagioclase, $\mathrm{Cr}$-spinel and $\mathrm{Fe}$-Ti-oxides, while secondary phases are mostly albite, chlorite, actinolite, prehnite, pumpellyite, epidote, white mica, calcite, quartz and K-feldspar. Interstitial glass is generally devitrified mainly to tiny quartz and albite crystals. Metamorphism and strong deformation obscured many of the original petrographical features of the greenschist-facies, lower metavolcanics. They are usually foliated with whitish bands mainly of quartz, calcite and albite, alternate with dark greenish bands enriched in chlorite, biotite, epidote or actinolite. Many arguments indicate that the protoliths of the metavolcanics were developed in a marginal basin - volcanic arc system. In particular, upper metavolcanics having high LIL/HFS element ratios and depleted REE contents were formed in an immature island arc setting, while the lower metavolcanics present both weak MORB and strong VAB characters suggesting that their protoliths developed in a short-lived back-arc basin (Magganas et al. 1991). The most primitive protoliths of the upper metavolcanics were produced in the fore-arc area by about $30 \%$ partial melting of an already depleted mantle source, due to an earlier partial melting event that had generated the magma of the lower metavolcanic protoliths in an extensional regime. The marginal basin was part of the Vardar or Meliata Ocean nearby the promontory of the continental crust of the Rhodope Massif (Magganas et al. 1991, Magganas 2002, Bonev and Stampfli 2003). The Evros ophiolite rocks incorporated in the shallow levels of an accretionary prism composed both of Circum Rhodope Belt and Rhodope Massif rocks (Ricou et al. 1998, Barr et al. 1999) probably shortly after their formation during Late Cretaceous. Afterward, they uplifted, overthrusted onto Rhodope massif and finally suffered the general extensional deformation in the area during early Tertiary and partially intruded and/or covered by Paleocene to recent igneous rocks and sedimentary formations (Magganas 2005).

\section{Analytical Methods - Alteration}

Mineral and rock identification were made using common optical microscopy methods. Mineral chemistry data were obtained by a JEOL-5600 SEM-EDS at the University of Athens, Department of Mineralogy and Petrology Laboratory. Major, trace and rare earths elements whole rock analyses (Table 1) were performed at ACME Analytical Laboratories LTD, Vancouver, Canada. Major elements analyzed by ICP-ES method, with sample fused by $\mathrm{LiBO}_{2} / \mathrm{Li}_{2} \mathrm{Bi}_{4} \mathrm{O}_{7}$ flux, LOI by Loss on Ignition and Total $\mathrm{C}$ and $\mathrm{S}$ by LECO. Trace elements and REE obtained by ICP-MS method, with samples decomposed after $\mathrm{LiBO}_{2} / \mathrm{Li}_{2} \mathrm{Bi}_{4} \mathrm{O}_{7}$ flux fusion or acid treatment with $\mathrm{HCl}$ $\mathrm{HNO}_{3}-\mathrm{H}_{2} \mathrm{O}$ mixture. Synthetic materials or physical minerals were used as standards for mineral chemistry results, while geochemical rock data were checked by simultaneous analyses of international rock standards and duplicates. As particular care was taken both in the field for collecting fresh homogenous samples and during lab sample preparation, the obtained chemical analyses do not indicate any noteworthy variations in chemistry that could be ascribed to significant post-crystallization alteration and/or hydrothermal metamorphism. So, the geochemical data and especially those of trace elements and REE, generally considered as immobile elements, can be assumed to reflect primary magmatic contents. On the other hand, certain major element content and in particular sodium and calcium content should be considered with care, due to relatively abundant presence of secondary albite and epidote in the plagiogranite bodies, though the samples analysed were taken in areas clear of epidote clots (see below). 
Table 1 - Major, trace and rare earth elements analysed for Evros ophiolite plagiogranites. $\mathrm{NA}=$ not analysed. $\mathrm{Mg \#}=100 \cdot \mathrm{Mg} /\left(\mathrm{Mg}^{\mathrm{F}} \mathrm{Fe}^{2+}{ }_{\text {tot }}{ }^{*}\right)$ with $\mathrm{Fe}^{2+}{ }_{\text {tot }}{ }^{*}=\mathrm{Fe}^{2+}{ }_{\text {tot }} \cdot \mathbf{0}, 723 . \mathrm{HST}=\mathrm{High}$ Silica Trondhjemite, LST $=$ Low Silica Trondhjemite, TNL $=$ Tonalite

\begin{tabular}{|c|c|c|c|c|c|c|c|c|c|c|c|c|}
\hline Sample & DD13b & DD7eI & DD10a & DD3 D & DD9b 4104 & Sample & DD13b & DD7eI & DD10a & DD3I & DD9b & 4104 \\
\hline RockType & HST & HST & HST & LST & LST TNL & $R E E$ & & & & & & \\
\hline $\mathrm{SiO}_{2}$ & 76,49 & 76,81 & 78,22 & 63,896 & $67,4753,10$ & $\mathbf{L a}$ & 8,8 & 13,4 & 5,6 & 6,9 & 3,7 & 4,5 \\
\hline $\mathrm{TiO}_{2}$ & 0,21 & 0,19 & 0,20 & 0,85 & $0,82 \quad 0,77$ & $\mathrm{Ce}$ & 26,4 & 37,4 & 20,6 & 21,3 & 9,6 & 8,3 \\
\hline 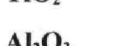 & 1162 & 1191 & 1176 & 1491 & & Pr & 4,1 & 5,3 & 2,9 & 3,0 & 1,5 & NA \\
\hline $\mathrm{Al}_{2} \mathrm{O}_{3}$ & 11,02 & 11,91 & 11,10 & 14,911 & $14,1 / 19,10$ & Nd & 19,9 & 25,5 & 15,7 & 15,6 & 8,1 & 6,4 \\
\hline $\mathrm{Fe}_{2} \mathrm{O}_{3}$ & 2,93 & 1,64 & 1,29 & 6,26 & $4,89 \quad 8,14$ & $\mathrm{Sm}$ & 5,9 & 7,4 & 5,1 & 5,2 & 2,4 & 1,8 \\
\hline MnO & 0,03 & 0,01 & 0,01 & 0,10 & $0,04 \quad 0,13$ & $\mathbf{E u}$ & 1,24 & 1,56 & 1,31 & 1,63 & 0,87 & 0,72 \\
\hline MgO & 0,41 & 0,15 & 0,26 & 1,78 & $1,84 \quad 3,50$ & Gd & 7,72 & 9,74 & 6,80 & 6,03 & 3,37 & NA \\
\hline $\mathrm{CaO}$ & 1,72 & 3,03 & 1,80 & 3,50 & $0,93 \quad 9,60$ & Tb & 1,52 & 1,86 & 1,35 & 1,18 & 0,65 & 0,28 \\
\hline $\mathrm{Na}_{2} \mathrm{O}$ & 4,62 & 4,92 & 4,98 & 5,71 & $5,38 \quad 2,00$ & Dy & 9,32 & 12,43 & 8,89 & 7,38 & 3,82 & NA \\
\hline $\mathbf{K}_{2} \mathbf{O}$ & 0,33 & 0,12 & 0,27 & 0,14 & $0,38 \quad 0,56$ & Но & 2,12 & 2,63 & 1,99 & 1,67 & 0,93 & 0,53 \\
\hline $\mathbf{P}_{2} \mathbf{O}_{5}$ & 0,03 & 0,02 & 0,03 & 0,11 & $0,14 \quad 0,05$ & $\mathbf{E r}$ & 6,67 & 7,93 & 6,48 & 5,01 & 2,95 & NA \\
\hline LOI & 1,50 & 1,20 & 1,20 & 3,30 & $3,20 \quad 3,02$ & $\mathbf{T m}$ & 1,06 & 1,20 & 0,95 & 0,76 & 0,43 & NA \\
\hline TOT/C & 0,04 & 0,03 & 0,02 & 0,44 & $0,06 \mathrm{NA}$ & $\mathbf{Y b}$ & 6,23 & 7,23 & 6,06 & 4,83 & 2,76 & 1,64 \\
\hline TOT/S & 0,01 & 0,01 & 0,01 & 0,01 & $0,01 \quad \mathrm{NA}$ & Lu & 1,01 & 1,16 & 1,02 & 0,78 & 0,40 & 0,34 \\
\hline TOTAL & 99,891 & 100,00 & 100,021 & $100,55 \mathrm{~s}$ & $99,8699,97$ & & & & & & & \\
\hline & & & & & & $\mathbf{A} / \mathbf{N K}$ & 1,46 & 1,45 & 1,39 & 1,56 & 1,59 & 4,90 \\
\hline $\mathbf{B a}$ & 38 & 21 & 23 & 15 & $47 \mathrm{NA}$ & $\mathrm{A} / \mathrm{CNK}$ & 1,05 & 0,87 & 1,00 & 0,94 & 1,35 & 0,89 \\
\hline $\mathrm{Be}$ & 1 & 1 & 1 & 1 & $<1 \quad \mathrm{NA}$ & $\mathrm{K}_{2} \mathrm{O} / \mathrm{Na}_{2} \mathrm{O}$ & 0,07 & 0,02 & 0,05 & 0,02 & 0,07 & 0,28 \\
\hline Co & 38 & 31 & 16 & 23 & $33 \mathrm{NA}$ & Mg\# & 21,7 & 15,3 & 28,5 & 36,0 & 42,7 & 48,1 \\
\hline Cs & 0,6 & 0,1 & 0,4 & 0,2 & $1,0 \quad \mathrm{NA}$ & $\mathbf{E} \mathbf{u}^{*} / \mathbf{E} \mathbf{u}_{\mathbf{n}}$ & 0,54 & 0,58 & 0,67 & 0,88 & 0,96 & ${ }^{8} 1,13$ \\
\hline Ga & 17 & 19 & 15 & 16 & $16 \mathrm{NA}$ & $\mathbf{L} \mathbf{a}_{\mathbf{n}} / \mathbf{Y} \mathbf{b}_{\mathbf{n}}$ & 0,96 & 1,25 & 0,62 & 0,97 & 0,89 & 1,90 \\
\hline Hf & 7,6 & 7,1 & 7,3 & 6,4 & $3,2 \quad 1,4$ & $\mathbf{L a}_{\mathbf{n}} / \mathbf{S m}_{\mathrm{n}}$ & 0,94 & 1,14 & 0,69 & 0,83 & 0,97 & 1,57 \\
\hline Nb & 1,9 & 2,2 & 2,0 & 1,4 & $1,0 \quad 1,0$ & $C \mathbf{e}_{\mathbf{n}} / \mathbf{Y} \mathbf{b}_{\mathbf{n}}$ & 1,10 & 1,34 & 0,87 & 1,15 & 0,89 & 1,34 \\
\hline $\mathbf{R b}$ & 11 & 3 & 7 & 3 & 12 & $\mathrm{Ce}_{\mathrm{n}} / \mathrm{Sm}_{\mathrm{n}}$ & 1,08 & 1,22 & 0,97 & 0,99 & 0,97 & 1,11 \\
\hline Sr & 76 & 101 & 69 & 92 & $\begin{array}{ll}89 & 191\end{array}$ & $\mathbf{E} \mathbf{u}_{\mathbf{n}} / \mathbf{Y} \mathbf{b}_{\mathbf{n}}$ & 0,55 & 0,63 & 0,61 & 0,95 & 0,91 & 1,24 \\
\hline Ta & 0,6 & 0,6 & 0,3 & 0,3 & $0,4 \quad 0,1$ & EREE & 101,901 & 134,70 & 84,908 & 81,30 & $41,60^{8} 3$ & 31,40 \\
\hline Th & 2,6 & 2,7 & 2,6 & 1,3 & $1,3 \quad 0,9$ & & & & & $\S_{\text {Extra }}$ & apolated & $d$ values \\
\hline $\mathbf{U}$ & 0,6 & 0,7 & 0,6 & 0,3 & $0,4 \quad 0,3$ & CIPW norms & & & & & & \\
\hline V & 6 & $<5$ & $<5$ & 66 & 89 NA & $Q$ & 44,14 & 42,12 & 44,062 & 20,733 & 30,38 & 14,93 \\
\hline W & 542 & 468 & 279 & 197 & 393 NA & $C$ & 0,61 & 0,00 & 0,07 & 0,00 & 4,15 & 0,00 \\
\hline $\mathbf{Z r}$ & 241 & 242 & 240 & 228 & $87 \quad 50$ & Or & 1,95 & 0,71 & 1,60 & 0,83 & 2,25 & 3,31 \\
\hline $\mathbf{Y}$ & 60 & 74 & 55 & 45 & $25 \quad 17$ & $A b$ & 39,09 & 41,63 & 42,144 & 48,32 & 45,52 & 16,92 \\
\hline Мo & 0,2 & 0,2 & 0,1 & 0,1 & $0,2 \quad \mathrm{NA}$ & $A n$ & 8,34 & 10,06 & 8,731 & 14,64 & 3,70 & 41,48 \\
\hline $\mathrm{Cu}$ & 0,7 & 0,4 & 0,2 & 0,6 & $14,8 \quad \mathrm{NA}$ & Di & 0,00 & 0,81 & 0,00 & 0,00 & 0,00 & 2,84 \\
\hline $\mathrm{Ni}$ & 0,3 & 0,2 & 0,2 & 0,4 & $2,1 \quad \mathrm{NA}$ & Wo & 0,00 & 1,33 & 0,00 & 0,00 & 0,00 & 0,00 \\
\hline $\mathrm{Cr}$ & 7 & 7 & 7 & 7 & 14 NA & $H y$ & 1,02 & 0,00 & 0,65 & 4,43 & 4,58 & 7,40 \\
\hline Se & 6 & 6 & 6 & 18 & $15 \quad 26$ & II & 0,06 & 0,02 & 0,02 & 0,21 & 0,09 & 0,28 \\
\hline Cd & $<0,1$ & $<0,1$ & $<0,1$ & $<0,1$ & 0,2 NA & $\mathrm{Hm}$ & 2,93 & 1,64 & 1,29 & 6,26 & 4,89 & 8,14 \\
\hline Sb & 0,4 & 0,3 & 0,1 & 0,3 & 0,6 NA & Tn & 0,00 & 0,44 & 0,00 & 1,41 & 0,00 & 1,53 \\
\hline Au & 1,6 & 1,2 & $<0,5$ & $<0,5$ & 9,3 NA & $R u$ & 0,18 & 0,00 & 0,19 & 0,16 & 0,78 & 0,00 \\
\hline $\mathrm{Hg}$ & 0,02 & 0,03 & 0,03 & $<0,01$ & 0,08 NA & Ap & 0,07 & 0,05 & 0,07 & 0,26 & 0,33 & 0,12 \\
\hline TI & 0,1 & $<0,1$ & $<0,1$ & $<0,1$ & $<0,1 \quad$ NA & Sum & 98,39 & 98,80 & 98,829 & $97,26 \mathrm{c}$ & 96,67 & 96,95 \\
\hline
\end{tabular}




\section{Mineralogical, Petrographical and Geochemical Data}

Two major and one minor type of plagiogranitic rocks can be distinguished in Evros ophiolite. The first one [corresponding to a low silica trondhjemite (LST) - see below] is grey-greenish medium grained (up to $3 \mathrm{~mm}$ ) rocks outcropping mostly as dykes in the area of Didymotycho. They show granular texture and mainly consist of plagioclase ( $\sim 30-50 \mathrm{vol} . \%)$ and interstitial quartz $(\sim 20-30$ wt.\%). The plagioclase is albite $\left(\mathrm{An}_{0-5}\right)$, while mafic primary minerals are virtually absent. Instead, abundant chlorite after amphibole and epidote prevail. The assemblage also contains apatite, titanite, zircon and opaques, which include ilmenite, Mn-rich ilmenite and hematite. The rocks show no signs of plastic deformation with isometric quartz crystals without undulatory extinction.

The second petrologic type [corresponding to a high silica trondhjemite (HST) - see below] has a light greenish-grey to whitish colour and is the prevailing rock type of the stock in the area of Didymotycho. It usually shows a spotted texture due to greenish clots consisting of spherulitic and prismatic, occasionally zoned, hydrothermal epidote. Abundant quartz ( $>35 \mathrm{vol} . \%)$ and plagioclase (now albite) predominate in the rock, while $\mathrm{K}$-feldspar is totally devoid and no any indication exist for its replacement. Other accessory or secondary minerals in the rocks are chlorite, rutile, white mica, which is usually found as irregular patches and exceptionally as corona surrounding epidote, zircon, allanite, Fe-Ti-oxides, pyrite, calcite, apatite and xenotime. Equigranular texture predominates in the rock. In many places granophyric to micrographic texture between albite and vermiform quartz intergrowth is present. This texture is interpreted as primary formed during magmatic crystallization at eutectic conditions (Coleman and Donato 1979). Few Carlsbad albite twins also indicate formation from a melt than a secondary hydrothermal origin. In opposite, some recrystallized quartz crystals were formed under low stress post-magmatic conditions, indicated by grains with triple junction at $120^{\circ}$ boundaries.

In the area of Makri a small occurrence of a medium grained plagiogranitic rock was discovered.
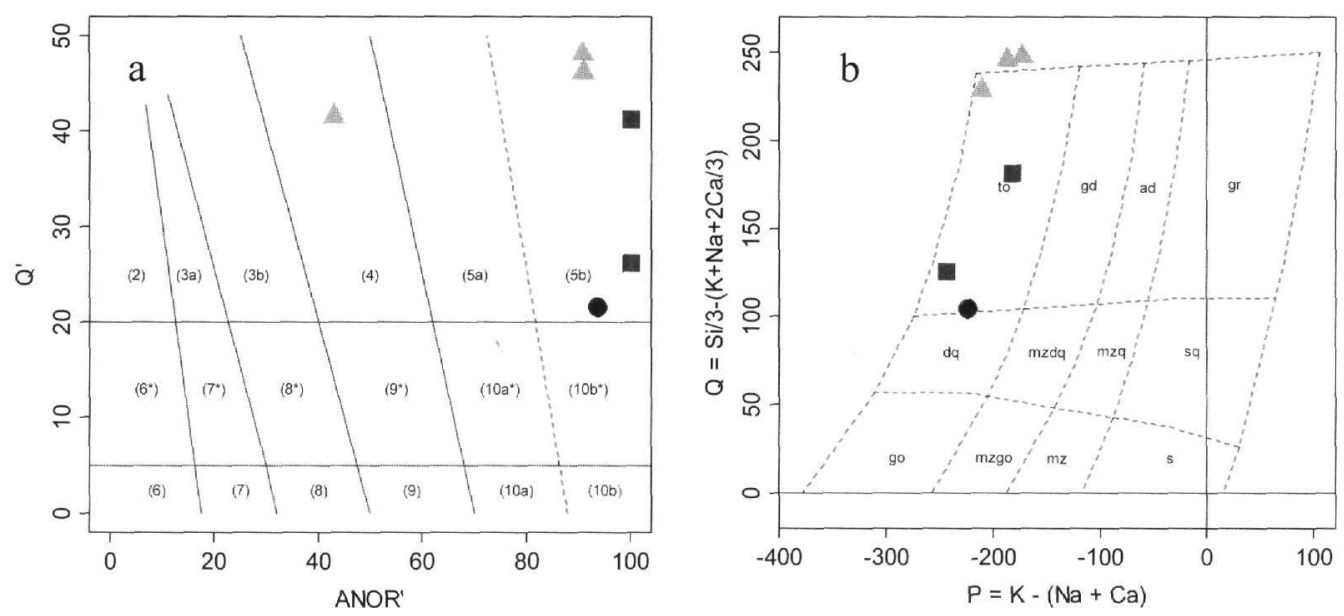

Figure 2 - (a) Q' vs. ANOR' classification plot of Streckeisen and Le Maitre (1979). (b) Nomenclature diagram of Debon \& Le Fort (1983). Triangles $=$ HST, Squares $=$ LST, Circle $=$ Tonalite. Fields: $(4)=$ granodiorite, $(5 \mathrm{~b})$ and "to" $=$ tonalite - trondhjemite 
Its felsic and mafic mineralogical constituents are set in a granoblastic to intergranular or poikilitic texture. Almost pure albite and quartz occupy more than 60 vol.\% of the rock, while among mafic minerals epidote prevails and chlorite, titanite and sub-idiomorphic to skeletal opaque Fe-Tioxides are also present. The rock corresponds to a tonalite (TNL) composition (see below).

The above mentioned primary petrographic features of the plagiogranitic types, and especially the presence of interstitial mineral assemblages of late stage, the development of granophyric textures and Carlsbad twins, and the absence of cumulate textures, along with some larger-scale structures that they usually show, such as intrusions in the form of fine grained dykes, presence of chilled margins and enclaves evidence that the Evros plagiogranitic rocks can be regarded as frozen melts rather than as cumulates.

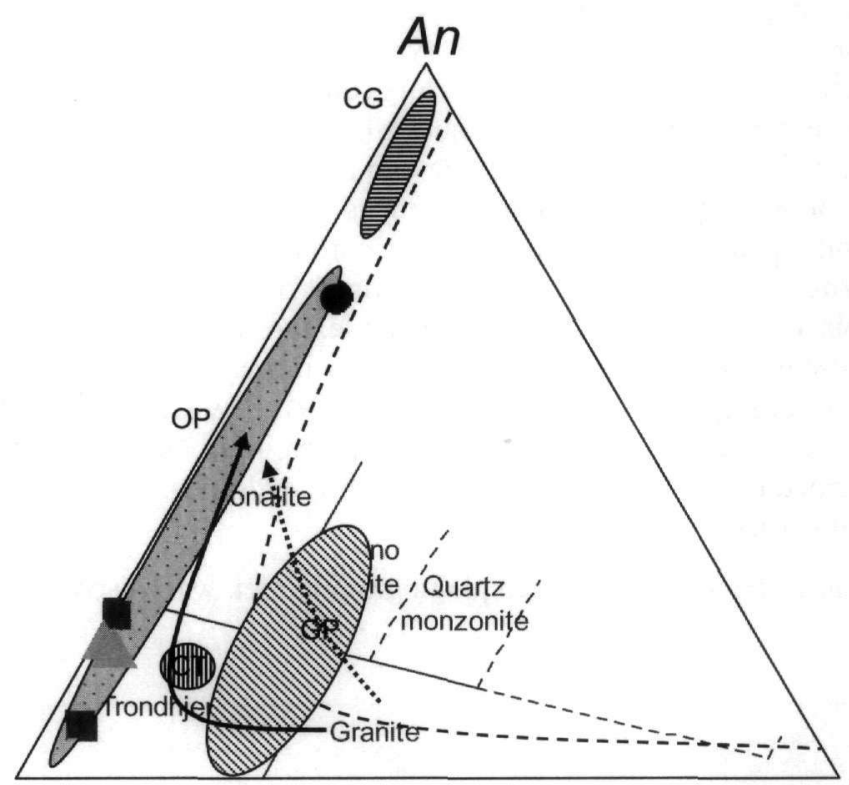

$A b$

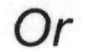

Figure 3 - Samples plotted on the CIPW normative $A b$, An and $\mathrm{Or}$ triangular diagram of $\mathrm{O}^{\prime} \mathrm{Connor}(1965)$. $\mathrm{CG}=$ Cumulate Gabbro, OP = Oceanic Plagiogranite, $\mathrm{CT}=$ Continental Trondhjemite, GP $=$ Granophyre. Area left and below of dashed line: Low-P ( $<5 \mathrm{~kb})$ field. Solid arrow: composition of partial melts of basaltic rocks under waterdeficient conditions and high-P ( $>5 \mathrm{~kb})$, dotted arrow: composition of partial melts of basaltic rocks under watersaturated conditions and high-P ( $>5 \mathrm{~kb}$ ) (after Springer and Seek 1997). Symbols as in Figure 2
For the classification of the Evros plagiogranite geochemical and mineralogical normative data were used. Didymotycho plagiogranites define two geochemically different rock groups. The first group, those found mostly as dykes, has low silica content with $\mathrm{SiO}_{2}$ ranging from 63 to $68 \mathrm{wt} \%$, whereas the second one, that appeared in stock form, show high $\mathrm{SiO}_{2}$ content from about 76 to 79 wt.\%. The Makri plagiogranite is very low in silica at about 53 wt.\%. Plotting meso-normative mineral compositions for granitoids of Mielke \& Winkler (1979) on the Q' vs. ANOR' classification plot of Streckeisen and Le Maitre (1979) (Fig. 2a), as well as cationic proportions of quartz, $\mathrm{K}$-feldspar and plagioclase in the nomenclature diagram of Debon and Le Fort (1983) (Fig. 2b) the analysed rocks classified as tonalitestrondhjemites. An exception is noted for a high silica plagiogranite sample, which is

plotted onto the granodiorite area of the first diagram. For distinguishing between tonalitestrondhjemites the CIPW normative $A b, A n$ and $O r$ triangular diagram of O'Connor (1965) was used (Fig 3). In this plot all Didymotycho samples, as having $A b / A n$ ratios lower than 0,2 , are classified as trondhjemites, while sample from Makri as tonalite. Thus, the first group of Didymotycho plagiogranitic samples can be defined as low silica trondhjemites (LST) and the other one as high silica trondhjemites (HST). LST are similar to the leucogranites of the Samothraki ophiolite (Tsikouras et al. 1998) in mineralogical and geochemical composition, except for the presence of K-feldspar in the latter. 
A geochemical comparison between various plagiogranites in Evros ophiolite reveals that alumina content has opposite behaviour than silica. LST and tonalite show higher $\mathrm{Al}_{2} \mathrm{O}_{3}$ values $(\sim 15-19$ wt.\%) than HST ( $\sim 12$ wt.\%). However, in absolute values the alumina content of trondhjemites is generally low, analogous to aluminium-poor trondhjemites of Barker (1979) (Fig. 4a). Similarities between plagiogranitic samples are recognised in alkalies, all having higher sodium than potassium, the latter being extremely low for granitoids but within the $\mathrm{K}$ content of oceanic plagiogranites (Fig. 4b). The amount of normative $A b, O r$ and $A n$ mirrors this major element chemistry (Fig. 3). The analysed samples fall inside the range of oceanic plagiogranites, showing substantially less normative $O r$ values than continental trondhjemites and granophyres (Coleman 1977). Especially $O r$ content, which lies below $2,5 \%$ (Table 1), is similar, though somewhat lower to the plagiogranites from Samothraki (Tsikouras et al. 1998) and oceanic plagiogranites of Coleman (1977).
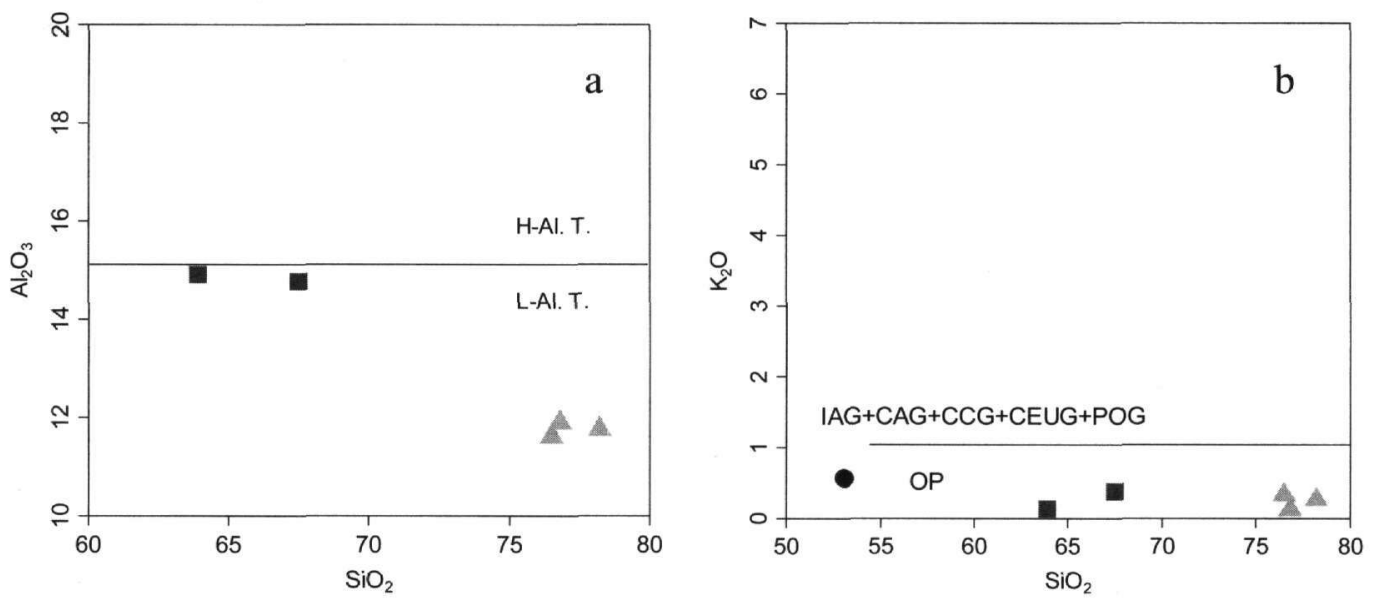

Figure 4 - (a). Plot of $\mathrm{Al}_{2} \mathrm{O}_{3}$ vs. $\mathrm{SiO}_{2}$ for Evros ophiolite plagiogranitic rocks. H-Al.T. = High-alumina trondhjemites, L-Al.T. = Low-alumina trondhjemites. Fields after Barker (1979). (b). Plot of $\mathrm{K}_{2} \mathrm{O}$ vs. $\mathrm{SiO}_{2}$ for Evros ophiolite plagiogranitic rocks. Fields after Maniar and Picolli (1989). OP = Oceanic Plagiogranites, IAG = Island Arc Granitoids, CAG = Continental Arc Granitoids, CCG = Continental Collision Granitoids, POG = Post-Orogenic Granitoids, CEUG $=$ Continental Epiorogenic Uplift Granitoids. Symbols as in Fig. 2

$\mathrm{Rb}$ and $\mathrm{Sr}$ concentrations, which follow $\mathrm{K}$ abundances, are also very low for granitoids, while relatively poor contents are observed for $\mathrm{Ba}$ and $\mathrm{Nb}$ too, with values less than $50 \mathrm{ppm}$ and $2 \mathrm{ppm}$ respectively. $\mathrm{Zr}$ and Y contents are somewhat higher in HST than LST and tonalite. On opposite, HST shows lower Mg\# values (15-30) than LST and tonalite (36-48). These major and trace elements concentrations correspond to oceanic plagiogranitic values. Thus, in most respects, the textural, mineralogical and geochemical characteristics of the Evros granitoids compare well with those of oceanic plagiogranites.

Evros plagiogranites are classified as metaluminous to slightly peraluminous as A/CNK ratios are lower than 1,05 for all samples except one LST that has 1,35 (Table 1). Moreover, such values as well as the presence of titanite, epidote and allanite instead of muscovite, garnet and monazite imply for I- and M-type granites (Chappell and White 1974, Whalen 1985). Hacker variation plots of several major and trace elements (not shown) reveal both sympathetic and antipathetic trends for Evros plagiogranites. Alumina, $\mathrm{MgO}$ and $\mathrm{FeO}^{\mathrm{t}}$ demonstrate strong negative correlation with silica, whereas $\mathrm{Zr}$ and $\mathrm{Y}$ show positive correlation. On the other hand, a significant slope change is 

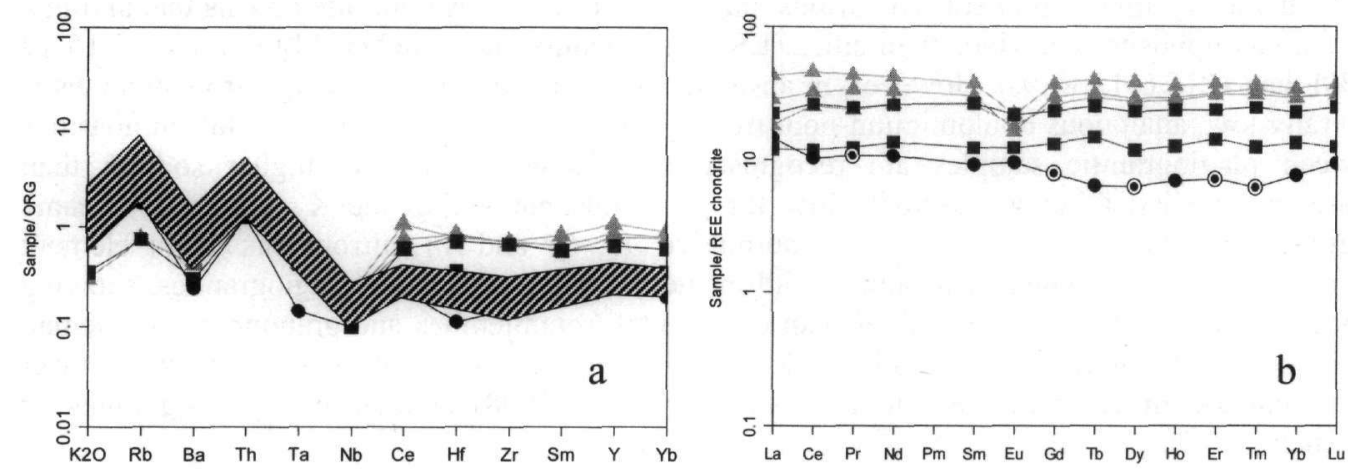

Figure 5 - (a). Rock/ORG (Ocean Ridge Granite) plot for Evros ophiolite plagiogranites with Pearce et al. (1984) normalizing values. The shaded envelope accounts for acid Evros ophiolite lavas (Porphyric felsites). (b). REE patterns for Evros ophiolite plagiogranites. Ringed dots represent extrapolated values. Symbols as in Fig. 2

depicted in some elements with increasing silica. Thus, $\mathrm{TiO}_{2}, \mathrm{Na}_{2} \mathrm{O}$ and $\mathrm{P}_{2} \mathrm{O}_{5}$ change from positive to negative, while $\mathrm{CaO}$ show opposite trend. A late fractionation of Ti-bearing oxides or silicates, apatite and allanite may be responsible for such behaviour.

Ocean Ridge Granites (ORG) normalized spidergrams (Fig. 5a) show that compatible elements have values close to ORG, while incompatible elements represent depleted values relative to ORG. $\mathrm{Ba}, \mathrm{Ta}$ and $\mathrm{Nb}$ negative anomalies, typical of plagiogranites from volcanic arcs or SSZ ophiolitic sequences, exist. Likewise, plagiogranites fall near to the boundary between ORG and VAG in the LILE vs. HFSE plots of Pearce et al. (1984) (Fig. 6). A comparison of chondrite normalized REE plots (Fig. 5b) for the three plagiogranitic types show that they have subparallel, relatively flat patterns at 10 to 50 times chondrite. $\Sigma$ REE contents are diminishing from HST to LST and tonalite, averaging from $\sim 107$ to $\sim 61$ and $\sim 31 \mathrm{ppm}$ respectively (Table 1). Negative Eu anomaly is higher in HST $\left(\mathrm{Eu}^{*} / \mathrm{Eu}_{\mathrm{n}}=0,54-0,67\right)$ than in LST $\left(\mathrm{Eu}^{*} / \mathrm{Eu}_{\mathrm{n}}=0,88-0,96\right)$. Tonalite have a slight positive $\mathrm{Eu}$ anomaly, which using extrapolated value for $\mathrm{Gd}$ is calculated to $\mathrm{Eu}^{*} / \mathrm{Eu}_{\mathrm{n}}=1,13$. The degree of REE fractionation in all types is approximately the same $\left(\mathrm{La}_{n} / \mathrm{Yb}_{\mathrm{n}}=0,62-0,96 ; 0,83-0,97\right.$; 1.90 and $\mathrm{La}_{\mathrm{n}} / \mathrm{Sm}_{\mathrm{n}}=0,69-1,14 ; 0,83-0,97 ; 1,57$ from HST to LST and tonalite respectively).

Though not any direct outcrop connection was recognized between acid plagiogranitic dykes and rhyolite-rhyodacite lavas (porphyric felsites) of the overlying Evros ophiolite volcanics (Magganas et al. 1991, Magganas 2002), their geochemical similarities (Fig. 5a) suggest the latter are
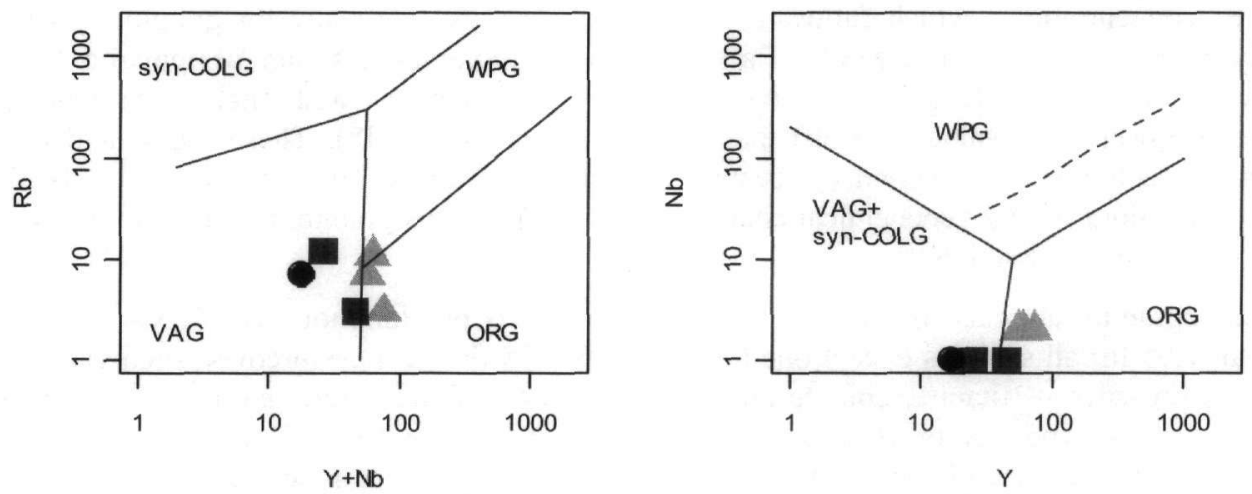

Figure 6 - Rb vs. $\mathrm{Y}+\mathrm{Nb}$ and $\mathrm{Nb}$ vs $\mathrm{Y}$ plots for Evros ophiolite plagiogranites. Fields after Pearce et al. (1984). WPG = Within Plate Granites, VAG = Volcanic Arc Granites, syn-COLG = syn-Collision Granites. Symbols as in Fig. 2 
extrusive equivalents of the former, and especially the LST dykes. In addition, porphyric felsites are found mostly within the northern occurrences of the Evros ophiolite at DidymotychoMetaxades and Melia areas, i.e. where acid plagiogranitic rocks occur. Analogous plagiogranite acid lavas association was described by Floyd et al. (1998) in the Sarikaraman Ophiolite, an ophiolitic complex originated from an SSZ environment at the eastward continuity of Vardar Ocean in Central Anatolia, Turkey.

\section{Plagiogranite Petrogenesis}

As recently summarized by Koepke et al. (2007), four models are generally accepted for the plagiogranite formation. The first one involves highly fractionated melts of low-K tholeiitic MORB magmas. The second model assumes 10-35\% hydrous partial melting of gabbroic or similar chemistry rocks in a tectonically unstable, due to shearing, MOR setting or at places of high-temperature hydrothermal activity. As third scenario for plagiogranite generation has been liquid immiscibility in an evolved MORB liquid has been suggested, whereas the fourth model explains the generation after assimilation and partial melting of previously altered dykes at the roof of a magma chamber located under fast spreading ridges. However, the last two models seem not to apply to Evros plagiogranitic rocks. Liquid immiscibility is excluded, firstly because immiscible melts in ophiolites exhibit a gap between 50 to 60 wt.\% $\mathrm{SiO}_{2}$ (Dixon and Rutherford 1979), which is not the present case as most plagiogranitic rocks studied possess greater $\mathrm{SiO}_{2}$ values, and secondly because average $\mathrm{Fe}_{2} \mathrm{O}_{3}{ }^{*}$ and $\mathrm{TiO}_{2}$ contents in the immiscible silicate melts (Philpotts 1982, Tsikouras et al. 1998) are significantly higher than those of the Evros plagiogranites (Table 1). As to the involvement of previously altered dykes, there is no evidence of such occurrence at the regional scale. On the other hand, as previously evidenced by geological, petrographical and geochemical arguments, the Evros ophiolite plagiogranitic rocks represent melts, either generated by partial melting or through fractional crystallization, rather than cumulates. Moreover, as plagiogranites are intimately associated to gabbroic and basaltic rocks, like in many ophiolites worldwide, these rocks or the melts generated these rocks could be potentially considered the most probable initial sources of the plagiogranites.

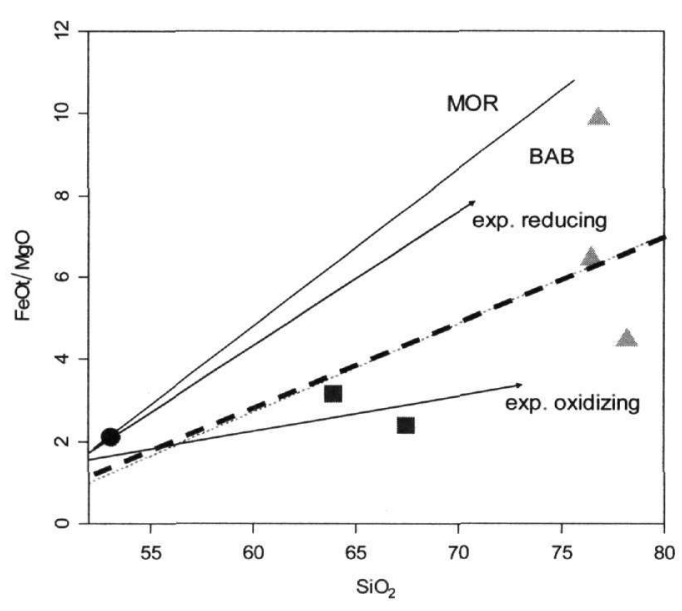

Figure 7 - FeOt/MgO vs. SiO2 plot for Evros ophiolite plagiogranites. Fields after Koepke et al. (2007). BAB = Back Arc basins, MOR = Mid Ocean Ridges. MORB differentiation under experimentally reducing and oxidi-zing conditions. Symbols as in Fig. 2

In the plot of $\mathrm{FeOt} / \mathrm{MgO}$ vs. $\mathrm{SiO}_{2}$ (Fig. 7) the linear regression line and the data points of Evros plagiogranites fall in the field of evolved rocks from BABs (Koepke et al. 2007). However, because of the large spread of the points, the redox conditions of plagiogranite genesis should be variable. Thus, the formation has to be more complex than a simple fractionation of Fe-Ti-oxides during a hydrous late stage differentiation of a MORB melt (Berndt et al. 2005).

In the REE patterns (Fig. 5b) negative Eu anomalies in HST are indicative of plagioclase participation during fractionation and/or melting. On the contrary, slightly positive Eu anomaly of tonalite could be ascribed to elevated $\mathrm{Sr}$ contents and can be a sign of a small quantity of accumulated Ca-rich feldspar (e.g. Birk et al. 1979, Floyd et al. 1998). The absence of negative Eu 
anomaly in LST, except restricted plagioclase fractionation, can be also attributed to local high $\mathrm{fO}_{2}$-oxidizing conditions (Fig. 7), which prevented formation of $\mathrm{Eu}^{2+}$.

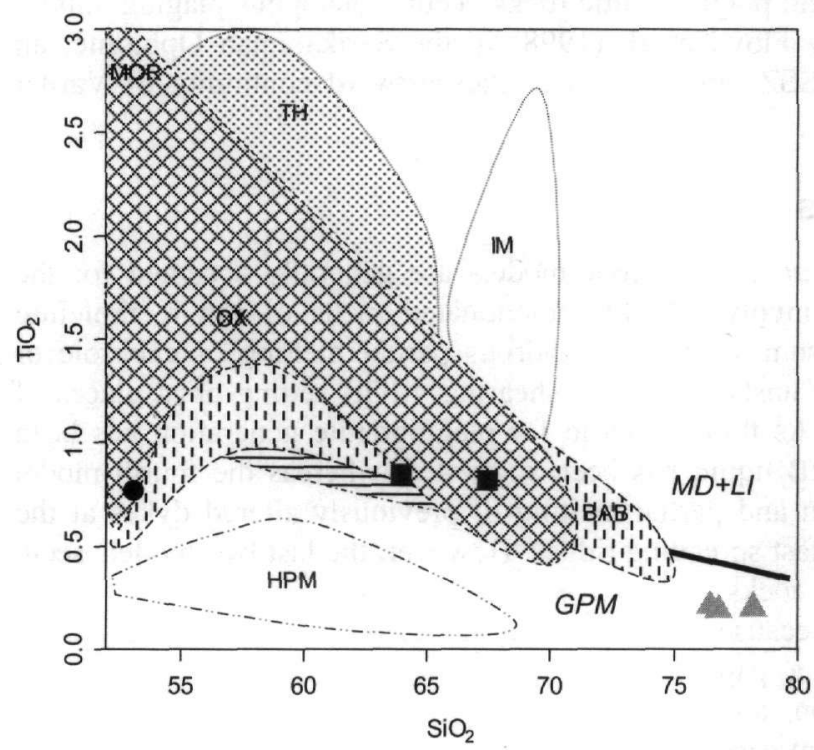

Figure 8 - $\mathrm{TiO}_{2}$ vs. $\mathrm{SiO}_{2}$ plots for Evros ophiolite plagiogranites. Fields after Koepke et al. (2007) are: MD+LI = MORB Differentiation + Liquid Immiscibility, GPM = Gabbros Partial Melting, MOR = MORB glasses, $\mathbf{B A B}=\mathbf{B A B}$ glasses, $\mathrm{OX}=\mathbf{M D}$ at Oxidizing Conditions, TH $=$ Tholeiitic melts at Reducing Conditions, IM = Immiscible Melts, HPM = Hydrous Partial Melting of Oceanic Gabbros. Symbols as in Fig. 2
Experimental results on gabbro partial melting under water-rich conditions (Koepke et al. 2004) demonstrate that at $900{ }^{\circ} \mathrm{C}$ the $\mathrm{SiO}_{2}$ content of extracted melts ranges between 63 and 68 wt. $\%$, i.e. a $\mathrm{SiO}_{2}$ content similar to that of Evros LST. Another indication for anatexis of pre-existing amphibole-bearing gabbroic rocks is suggested by the $\mathrm{TiO}_{2}$ vs. $\mathrm{SiO}_{2}$ contents (Fig. 8). In this diagram, both tonalite and HST plot below $\mathrm{TiO}_{2}$ limit for experimental MORB differentiation or liquid immiscibility, whereas LST plot close but above this limit. The close spatial association of hornblende gabbros and Evros plagiogranites supports for at least tonalite and HST, namely for the main plagiogranitic mass produced, an anatectical genesis within the deep oceanic crust.

Magganas et al. (1991) and Magganas (2002) demonstrated that the Evros dismembered ophiolite formed in a SSZ setting, i.e. an environment which comprises both

ridge and subduction parts. Moreover, Didymotycho-Metaxades and Melia extrusives from the Evros ophiolite display slightly different geochemical signatures, such as higher $\mathrm{Zr} / \mathrm{Y}$ ratios and ¿REE contents respect to the Maronia volcanic equivalents (Magganas 2002). Thus, a particular environment that likely formed the ophiolitic rocks occurring in the northern sector of the Evros ophiolite existed. The presence of plutonic rocks and especially of small, $\mathrm{SiO}_{2}$-enriched plagiogranitic stocks in the northern area supports this hypothesis. This peculiar setting is further suggested by the plots of Fig. 6 where plagiogranites fall within both ORG and VAG settings. A good explanation for the area seems to involve a shallow magma chamber under a restricted sheeted dyke complex, which proclaims for an extensional regime, while subducting slab fluid components raised and participated to the overall petrogenesis. Also, a transform fault area or an oceanic small core complex cannot be excluded, though more evidences for both settings to be definitely accepted are needed.

Conclusively and in spite of some uncertainties due to relatively few samples chemically analyzed, the following scenario for plagiogranite petrogenesis seems at present to be most plausible. Oceanic pyroxene \pm olivine gabbros underwent seawater and/or magmatic water metasomatism to form amphibole gabbros in deep oceanic crust. Seawater fluids may have entered the lower crust through detachment faults or other openings of tectonic origin. In a second stage heat offered in the area by a newly arrived mantle wedge magma batch, which might stayed underplating gabbroic rocks. Then, amphibole gabbros dehydrated, liberating water at high temperature $\left(\sim 900-1000{ }^{\circ} \mathrm{C}\right)$. Koepke et al. (2007) suggest that less that $1 \mathrm{wt} . \%$ water is enough in order to $10 \mathrm{wt} \%$ felsic melt produced at $\sim 1-2$ kbars. The released fluid lowered the solidus of the overlying gabbros causing 
their partial melting. The generated melt was silica rich at largely varying grades. As studied tonalite and $\mathrm{HST}$ have more than $20 \mathrm{wt} . \% \mathrm{SiO}_{2}$ content difference, I suggest that both can be produced by such or analogous procedures. In fact, the partial melting experiments of Koepke et al. (2004) shows that melts with $\mathrm{SiO}_{2}$ ranging from $~ 52$ to $68 \mathrm{wt} . \%$ can be created, and petrogenetic calculations of Floyd et al. (1998) and Luchitschaya et al. (2005) show that some 5-15\% partial melting of SSZ gabbroic rocks generate plagiogranitic melts with $\mathrm{SiO}_{2}$ ranging from $\sim 67$ to 80 wt.\%. The granitoid melt, being less dense than the surrounding basic rocks, reached to a shallow magma chamber and finally crystallized forming small stocks. As negligible geochemical differences between HST samples exist, none or very limited fractionation took place. In opposite, due to few partially resorbed enclaves found within HST some assimilation occurred during ascent or at the top or margins of the magma chamber.

On the other hand, LST may have been generated by fractional crystallization of a MORB or low$\mathrm{K}$ tholeiite type parental melt, which originated in the lower crust or escaped from the asthenosphere - lithosphere boundary moving upwards through fractures in an extensional environment. In this case, the felsic melt was less voluminous and intruded as veinlets or somewhat thicker dykes. Floyd et al. (1998) state that acid plagiogranitic melts could have been generated by fractional crystallization of $70-85 \%$ of clinopyroxene-feldspar \pm amphibole of a gabbroic source material.

In a final stage late intense shallow hydrothermal activity affected all plagiogranite rocks. As a result, widespread epidotization and perhaps some silicification of the rocks occurred, locally culminating in the formation of abundant epidositic clots or small quartz-epidote veins. A similar epidosite-plagiogranite association, where epidosite metasomatically replaced plagiogranite protoliths, is reported by Benerjee et al. (2000) in the modern SSZ setting of Tonga forearc in the Western Pacific.

\section{Conclusions}

a. Intrusive plagiogranitic rocks occurring below the extrusive volcanic complex of Evros ophiolite, NE Greece and in association with sheeted dykes are classified as tonalites, low silica and high silica trondhjemites. They are found mostly as dykes or form small stocks.

b. Mineralogical, petrographic and geochemical data are similar to those of other oceanic and ophiolitic plagiogranites of SSZ origin in Greece and elsewhere. Their normalized rock/ORG plots reveal ORG compatible element values, slightly depleted relative to ORG incompatible elements and $\mathrm{Ba}, \mathrm{Ta}$ and $\mathrm{Nb}$ negative anomalies. As such geochemical characteristics are found in the acid lavas (porphyric felsites) of Evros Ophiolite, it is suggested that plagiogranitic melts, especially of LST composition, presumably fed and generate them after further differentiation of small extent. In the chondrite normalized REE diagrams the plagiogranites show subparallel, relatively flat REE patterns at 10 to 50 chondrite values and variable Eu anomaly suggesting different degrees of plagioclase fractionation and/or local oxidizing conditions.

c. As a first approximation to the petrogenesis of Evros ophiolite plagiogranites, it is proposed that they likely formed by both partial melting and fractional crystallization processes. In particular, tonalite and HST could have been generated by 5-15\% oceanic gabbros batch partial melting, whereas LST may possibly produced by progressive fractional crystallization of a MORB type source. This scenario is supported by the occurrence of amphibole bearing gabbroic rocks and basaltic - andesitic dykes in close association with the plagiogranites, In a later stage intense hydrothermal metamorphism at greenschistfacies conditions affected the plagiogranites causing formation of peculiar epidositic spherical clots and veinlets. 


\section{Acknowledgments}

Thanks are due for SARG of National \& Kapodistrian University of Athens for financial support. Two anonymous reviewers are likewise gratefully acknowledged.

\section{References}

Barker, F., 1979. Trondhjemites, dacites and related rocks. Amsterdam, Elsevier, 659pp.

Barr, S., Temperley, S., and Tarney, J., 1999. Lateral growth of the continental crust through deep level subduction- accretion: a re-evaluation of central Greek Rhodope, Lithos, 46, 69-94.

Bébien, J., 1991. Enclaves in plagiogranites of the Guevgueli ophiolitic complex, Macedonia, Greece. In J. Didier and B. Barbarin (eds), Enclaves and granite petrology. Developments in petrology, vol 13, Amsterdam, Elsevier, 205-219.

Banerjee, R., Gillis, M., and Muehlenbachs, K., 2000. Discovery of epidosites in a modern oceanic setting, the Tonga forearc, Geology, 28, 151-154.

Berndt, J., Koepke, J., and Holtz, F., 2005. An experimental investigation of the influence of water and oxygen fugacity on differentiation of MORB at $200 \mathrm{MPa}$., J. Petrology, 46, 135-167.

Bigazzi, G., Del Moro, A., Innocenti, F., Kyriakopoulos, K., Manetti, P., Papadopoulos, P., Norelli, P., and Magganas, A., 1989. The magmatic intrusive complex of Petrota, west Thrace: age and geodynamic significance, Geol. Rhodopica, 1, 290-297.

Birk, D., Koljonen, J., and Rosenberg, J., 1979. Rare earth distribution in Archean granitoid plutons of the Wabigoonnn volcanic - plutonic belt, northwestern Ontario, Can. J. Earth Sci., 16, 270-289.

Bonev, G., and Stampfli, M., 2003. New structural and petrologic data on Mesozoic schists in the Rhodope (Bulgaria): geodynamic implications, C. R. Geoscience, 335, 691-699.

Bonev, G., and Stampfli, M., 2005. Compositional diversity of the Evros ophiolite, Thrace, northeastern Greece: field occurrences, preliminary petrologic and geochemical data on plutonic sequence and tectonic implications, Proc. 80 Aniv. Jubilee meeting Bulg. Geol. Soc. Sofia, 17-18 November, 28-31.

Chappell, W., and White, R., 1974. Two contrasting granite types, Pacific Geology, 8, 173-174.

Coleman, G., 1977. Ophiolites. Ancient oceanic lithospere? Berlin, Springer-Verlag, 229pp.

Coleman, G., and Donato, M., 1979. Oceanic plagiogranite revisited. In F. Barker (ed.), Trondhjemites, dacites and related rocks. Amsterdam, Elsevier, 149-167.

Debon, F., and Le Fort, P., 1983. A chemical-mineralogical classification of common plutonic rocks and associations, Trans. Royal Soc. Edinburgh, Earth Sciences, 73, 135-149.

Dick, B., Ozawa, K., Meyer, S., Niu, Y., Robinson, T., Constantin, M., Hebert, R., Maeda, J., Natland, H., Hirth, G., and Mackie, M., 2002. Primary silicate mineral chemistry of a 1.5$\mathrm{km}$ section of very slow spreading lower ocean crust: ODP Hole 735B, Southwest Indian Ridge. In H. Natland, B. Dick, J. Miller, and P. Von Herzen (eds), Proceedings of ODP, Science Research, College Station, 176(10), 1-61.

Dixon, S., and Rutherford, J., 1979. Plagiogranites as late-stage immiscible liquids in ophiolite and mid-oceanic ridge suites: an experimental study, Earth Planet Sci Lett, 45, 45-60.

Floyd, A., Yaliniz, K., and Goncuoglu, C., 1998. Geochemistry and petrogenesis of intrusive and extrusive ophiolitic plagiogranites, central Anatolian Crystalline Complex, Turkey, Lithos, $42,225-241$. 
Frass, A., Hegewald, S., Kloos, M., Tesch, C., and Arikas, K., 1990. The geology of the graben of Petrota (Thrace, NE Greece), Geologica Rhodopica, 2, 50-63.

Hatzipanagiotou, K., and Tsikouras, B., 1999. Plagiogranites in the Hellenic ophiolites, Ofioliti, 24(2), 283-292.

Koepke, J., Feig, T., Snow, J., and Freise, M., 2004. Petrogenesis of oceanic plagiogranites by partial melting of gabbros: an experimental study, Contrib Miner Petrol, 146, 414-432.

Koepke, J., Jasper, Z., Berndt, Z., Feig, S., and Holtz, F., 2007. The formation of $\mathrm{SiO}_{2}$-rich melts within the deep oceanic crust by hydrous partial melting of gabbros, Contrib. Mineral. Petrol., 153, 67-84.

Luchitskaya, V., Morozov, L., and Palandzhyan, A., 2005. Plagiogranite magmatism in the Mesozoic island-arc structure of the Pekulney Ridge, Chukotka Peninsula, NE Russia, Lithos, 79, 251- 269.

Magganas, A., 1988. Mineralogical, petrological and geochemical study on metabasic and metaultrabasic rocks of Circum-Rhodope Belt in Thrace area, PhD thesis, University of Athens, Greece, 405pp.

Magganas, A., 2002. Constraints on the petrogenesis of Evros ophiolite extrusives, NE Greece, Lithos, 65, 165-182.

Magganas, A., 2005. Subgreenschist to greenschist facies metamorphism of metavolcanics of Circum-Rhodope Belt in Thrace, Bull. of Geol. Soc. Greece, 38, 78-89.

Magganas, A., Sideris, C., and Kokkinakis, A., 1991. Marginal basin-volcanic arc origin of metabasic rocks of the Circum-Rhodope Belt, Thrace, Greece, Mineralogy and Petrology, 44, 235-252.

Maniar, D., and Piccoli, M., 1989. Tectonic discriminations of granitoids, Geol. Soc. Amer. Bull., 101, 635-643.

Mielke, P., and Winkler, F., 1979. Eine bessere Berechnung der Mesonorm für granitische Gesteine, Neu. Jb. Mineral., Mh., 471-480

O'Connor, T., 1965. A classification for quartz-rich igneous rocks based on feldspar ratios, US Geological Survey Professional Paper, B525, 79-84.

Papadopoulos, P., 1982. Geological map of Greece, Scale 1:50.000 - Sheet Maronia, IGME, Athens.

Pearce, J., Harris, B., and Tindle, A., 1984. Trace element discrimination diagrams for the tectonic interpretation of granitic rocks, J. Petrol., 25, 956-983.

Philpotts, R., 1982. Compositions of immiscible liquids in volcanic rocks, Contrib. Miner. Petrol., $80,201-218$.

Ricou, E., Burg, J-P., Godfriaux, I., and Ivanov, Z., 1998. The Rhodope and Vardar: the metamorphic and the olistostromic paired belts related to the Cretaceous subduction under Europe, Geodin. Acta, 11, 285-309.

Springer, W., and Seck, A., 1997. Partial fusion of basic granulites at 5 to $15 \mathrm{kbar}$ : implications for the origin of TTG magmas, Contrib. Miner. Petrol., 127, 30-45.

Streckeisen, A., and Le Maitre, R., 1979. A chemical approximation to the modal QAPF classification of the igneous rocks, Neu. Jb. Mineral., Abh., 136, 169-206. 
Tsikouras, B., Hatzipanagiotou, K., and Seymour, K., 1998. Plagiogranite and leucogranite relationships in an ophiolite on the Tethys Ocean (Samothraki, N. Aegean, Greece), Neu. Jb. Mineral., Mh., 13-35.

von Braun, E., 1993. The Rhodope question viewed from Eastern Greece, Zeitschrift der Deutschen Geologischen Gesellschaft, 144, 406-418.

Whalen, B., 1985. Geochemistry of an island-arc plutonic suite: the Uasilau-Yau Yau Intrusive Complex, New Britain, P.N.G., Journal of Petrology, 26, 603-632. 